\title{
Pengaruh Pemberian Bakteri Hetrotrof Terhadap Kualitas Air pada Budidaya Lele Dumbo (clarias sp.) Tanpa Pergantian Air
}

\section{Effect of Heterotropic Bacteria Application on Water Quality of African Catfish (Clarias sp.) Aquaculture Without Water Circulation Method}

\author{
Dwi Ernawati ${ }^{1 *}$, Prayogo ${ }^{2}$, dan Boedi Setya Rahardja ${ }^{2}$ \\ ${ }^{1}$ Program Studi Budidaya Perairan, Fakultas Perikanan dan Kelautan, Universitas Airlangga, Surabaya \\ ${ }^{2}$ Departemen Manajemen Kesehatan Ikan dan Budidaya Perairan, Fakultas Perikanan dan Kelautan, Universitas \\ Airlangga, Surabaya \\ * dwi-e--fpk10.web.unair.ac.id
}

\begin{abstract}
Abstrak
Ikan lele dumbo (Clarias sp.) sebagai komoditas air tawar memiliki permintaan yang tinggi. Salah satu cara untuk memenuhi kebutuhan permintaan lele dumbo adalah perbaikan kualitas air sehingga produktifitas ikan semakin meningkat. Tujuan penelitian guna mengetahui pengaruh dari pemberian probiotik yang mengandung bakteri heterotrof berbeda pada perairan dan pengaruhnya terhadap kadar ammonia dan kadar nitrit pada media budidaya lele dumbo. Penelitian ini menggunakan metode eksperimental Rancangan Acak Lengkap (RAL). Ikan lele dumbo dipelihara selama 30 hari dengan empat perlakuan dan empat ulangan yaitu P1 (kontrol), P2 (probiotik A), P3 (probiotik B), dan P4 (probiotik C). Datahasil penelitian diolah menggunakan Analysis of Variance dan dilanjutkan Uji Berjarak Duncan karena didapatkan hasil yang berbeda nyata. Hasil dari penelitian menunjukkan bahwa pemberian probiotik yang mengandung bakteri heterotrof pada perairan mampu menekan produksi amonia dan nitrit yang berbeda nyata $(\mathrm{p}<0,05)$. Produksi kadar ammonia terendah adalah P4 sebesar 0,2093 $\pm 0,01483$, dan tertinggi pada P1 sebesar 0,2641 $\pm 0,01357$. Produksi kadar nitrit terendah pada P4 sebesar 0,0509 \pm 0,00644, dan tertinggi pada P1 sebesar 0, 0988 $\pm 0,00404$.
\end{abstract}

Kata kunci: bakteri heterotrof, amonia, nitrit, kualitas air

\begin{abstract}
A freshwater commodity such as the African catfish (Clarias sp.) has the high demand. One way to complete demand is to make the good water quality to get the high productivity. The aims of this research are known about the effect of different probiotic used which contain by heterotrophic bacteria against ammonia and nitrite production in the media. The research using experimental method, with the Completely Randomized Design (CRD). The African catfish kept in 30 days with four treatments and four replications, that is $\mathrm{P} 1$ (control), P2 (probiotic A), P3 (probiotic B), and P4 (probiotic C). The obtained data were processed by Analysis of Variance (ANOVA) and followed by Duncan Multiple Range Test because there was significant data. The result showed that the different probiotic used which contain by heterotrophic bacteria in the media giving the significant effect to ammonia and nitrite concentration. The lowest production of ammonia concentration in the media showed by P4 $0.2093 \pm$ 0.01483 and the highest production of ammonia concentration in the media showed by P1 $0.2641 \pm 0.01357$. The lowest production of nitrite concentration in the media showed by P4 $0.0509 \pm$ 0.00644 , and the highest production of nitrite concentration in the media showed by P1 $0.0988 \pm 0.00404$
\end{abstract}

Keywords: heterotrophic bacteria, amonia, nitrite, water quality

Diterima/submitted:29 September 2014 Disetujui/accepted:1 Maret 2016 


\section{Pendahuluan}

Ikan lele merupakan satu dari banyak spesies ikan air tawar yang dibudidayakan di Indonesia. Ikan lele dapat dikembangkan ke semua daerah sebagai penyediaan protein hewani serta peningkatan pen-dapatan masyarakat. Produksi ikan lele di Indonesia pada rentang waktu antara tahun 2005- 2009 menunjukkan peningkatan produksi ratarata sebesar $31,55 \%$ per tahun, dengan nilai produksi 486.166.245 ton menjadi 1.434.956.984 ton (KKP, 2011). Permintaan pasar akan ikan lele dumbo telah berkembang pesat kenaikan hingga mencapai $18,7 \%$ per tahun, karena ikan lele dumbo mempunyai keunggulan dibanding dengan ikan lele lokal dimana pertumbuhannya lebih cepat, dapat mencapai ukuran lebih besar dan lebih banyak kandungan telurnya (Mahyuddin, 2007).

Budidaya lele tanpa pergantian air dapat menghemat pemakaian air sehingga lebih ekonomis, dan dapat slakukan secara intensif. Sisa pakan ikan, hasil ekskresi organisme dan plankton yang mati serta material organik seperti padatan yang tersuspensi maupun padatan yang larut masuk melewati sumber air (inflow water) merupakan sumber bahan organik pada media pemeliharaan. Hal ini menyebabkan akumulasi bahan organik di perairan. Input bahan organik semakin bertambah beriringan dengan aktivitas kegiatan budidaya karena kebutuhan pakan organisme akuatik mengikuti pertumbuhan biomassanya (Boyd, 1990).

Sistem budidaya tanpa pergantian air menyebabkan akumulasi sisa pakan, feses, dan kualitas air yang buruk ( Sitompul dkk. 2012). Selain itu, menurut Spotte (1970), sisa pemberian pakan yang akan menghasilkan bahan organik yang akan membentuk ammonia, nitrit, dan nitrat. Ammonia pada perairan mampu menyebabkan kematian pada ikan apabila kandungannya terlalu tinggi, yaitu lebih dari $0,8 \mathrm{mg} / \mathrm{L}$
(Stickney, 2005), sedangkan nitrit akan bersifat toksik apabila kadar nitrit dalam perairan lebih dari $0,05 \mathrm{mg} / \mathrm{L}$ (Moore, 1991).

Bakteri heterotrof merupakan salah satu agen biologis yang berperan sebagai organisme pengurai sisa pakan dan bahan organik di dasar perairan. Dengan pemberian bakteri heterotrof ini diharapkan mampu menurunkan kadar ammonia dan nitrit pada budidaya lele tanpa pergantian air. Menurut Avnimelech (1999), adanya pemanfaatan nitrogen anorganik oleh bakteri heterotrof mencegah terjadinya akumulasi nitrogen dari bahan anorganik di dalam kolam budidaya sehingga mampu menurunkan kualitas air. Bakteri heterotrof memanfaatkan ammonia sebagai sumber energi untuk regenerasi sel (Todar, 2002).

\section{Materi dan Metode Waktu dan Tempat}

Penelitian dilaksanakan di Laboratorium Pendidikan Fakultas Perikanan dan Kelautan pada bulan Juni-Juli 2014.

\section{Alat dan Bahan}

Alat yang digunakan dalam penelitian ini adalah: $\mathrm{pH}$ meter, spektrofotometer, cuvet, tabung reaksi, gelas ukur, DO meter, $\mathrm{pH}$ meter, pipet tetes, termometer, jaring, timbangan digital, penggaris, ember, bak plastik 16 buah volume 15 $\mathrm{L}$, aerator, selang aerasi dan batu aerasi. Bahan yang akan digunakan dalam penelitian ini adalah bakteri probiotik "A" (Bacillus subtilis, Bacillus apiarius, Lactobacillus plantarum, dan Nitrosomonas eropea) dengan total count $1 \times 10^{6} \mathrm{CFU}$, "B" (Bacillus subtilis dan Bacillus licheniformes) dengan total count $1 \times 10^{7} \mathrm{CFU}$ dan "C", (Bacillus subtilis, dan Bacillus licheniformes) dengan total count $1 \times 10^{12} \mathrm{CFU}$, lele dumbo ukuran $9 \mathrm{~cm}$, larutan Nessler, aquades, NED (Napthil ethilen diamin) - 
dihidroklorida, larutan sulfanilamide, larutan standar amonia $(0,1 ; 0,2 ; 0,3 ; 0,4 ; 0,5 \mathrm{ppm})$, larutan standar nitrit $(0,025 ; 0,05 ; 0,1 ; 0,25$; $0,5 ; 0,1 \mathrm{ppm})$.

\section{Metode Penelitian}

\section{Persiapan Media dan Persiapan Benih}

Persiapan yang digunakan yaitu bak plastik dengan volume $15 \mathrm{~L}$. Sterilisasi air media dilakukan dengan menggunakan Kalium Permanganat dengan dosis $3 \mathrm{~g} / \mathrm{m}^{3}$, selanjutnya didiamkan selama sehari dan dilakukan pergantian air baru (Shaffrudin dkk., 2006). Benih yang digunakan disortir berdasarkan kualitas dan ukuran terlebih dahulu dan dilakukan penimbangan berat dan pengukuran panjang awal. Benih yang akan digunakan adalah jenis ikan lele dumbo dengan ukuran panjang $9 \mathrm{~cm}$.

Sebelum ditebar benih diaklimatisasi terlebih dahulu selama 5 menit. Benih ikan lele dumbo kemudian dimasukkan ke dalam bak plastik, dengan padat tebar masingmasing 1000 ekor $/ \mathrm{m}^{3}$ (Shaffrudin dkk., 2006), sehingga didapatkan padat tebar 30 ekor/bak.

\section{Pemeliharaan}

Selama pemeliharaan, pemberian pakan ikan lele dumbo dilakukan dengan frekuensi tiga kali yaitu pada pukul 08.00 pagi, 12.00 siang dan 16.00 sore. Pakan yang diberikan sejumlah 3\% dari berat tubuh ikan, mengacu pada Purnomo (2012), bahwa pemberian pakan ikan adalah sebanyak 3\% $5 \%$ dari berat tubuhnya. Pemberian jenis bakteri heterotrof diberikan langsung dengan dosis 0,03ml/15L (Andriyanto, 2010). Pemeliharaan ikan lele dumbo dilakukan selama 30 hari. Pengamatan dilakukan setiap dua hari sekali. Pengambilan sampel air untuk pengukuran amoniak dan nitrit dilakukan pada awal setelah benih ditebar, selanjutnya setiap dua hari sekali untuk mengetahui fluktuasi ammonia dan nitrit dalam media pemeliharaan. Untuk peng- ukuran suhu dan DO (Disolved Oxygen) dilakukan setiap pagi dan sore hari selama pemeliharaan.

\section{Pengukuran kadar Ammonia}

Penentuan kurva kalibrasi dengan cara menyiapkan larutan standar amoniak dengan konsentrasi 0,$1 ; 0,2 ; 0,3 ; 0,4 ; 0,5$ ppm, ppm masing - masing $50 \mathrm{ml}$. Selanjutnya adalah menambahkan larutan Nessler $1 \mathrm{ml}$ pada masing-masing konsentrasi, di kocok dan didiamkan selama 10 menit. Kemudian mengamati absorbansi masing-masing larutan pada panjang gelombang $425 \mathrm{~nm}$, dan membuat kurva kalibrasi.

Pengukuran kadar amoniak dilakukan mengunakan metode Nessler (Sari dkk., 2012) yaitu sampel sebanyak $50 \mathrm{ml}$, disaring dan dimasukkan kedalam Erlenmeyer $100 \mathrm{ml}$. Ditambahakan $1 \mathrm{ml}$ larutan Nessler kemudian dikocok dan dibiarkan selama 10 menit. Larutan sampel dimasukkan dalam cuvet, kemudian diukur dengan spektrofotometer dengan panjang gelombang $425 \mathrm{~nm}$.

\section{Pengukuran Kadar Nitrit}

(Metode Spektrofotometri (SNI 06-6989.92004).

Penentuan kurva kalibrasi dengan cara menyiapkan larutan standar nitrit dengan konsentrasi 0,$025 ; 0,05 ; 0,1 ; 0,25$; 0,5; 0,1 ppm masing - masing $50 \mathrm{ml}$. Menambahkan larutan sulfanilamide $1 \mathrm{ml}$ pada masing-masing konsentrasi, di kocok dan didiamkan selama dua menit. Ditambahkan $1 \mathrm{ml}$ larutan NED-dihidroklorida, dikocok dan didiamkan selama 10 menit. Mengamati absorbansi masingmasing larutan pada panjang gelombang 543 nm, dan membuat kurva kalibrasi.

Pengukuran kadar absorbansi sampel dengan cara mengambil air sampel sebanyak $50 \mathrm{ml}$, dan disaring dengan kertas saring, 
Tabel 1 Produksi kadar amonia selama 30 hari

\begin{tabular}{ccc}
\hline Perlakuan & Produksi amonia selama 30 hari \pm SD & Transformasi $\sqrt{ }(\mathbf{y}+\mathbf{0 , 5}) \pm$ SD \\
\hline P1 & $0,2641^{\mathrm{b}} \pm 0,01356$ & $0,8741 \pm 0.0078128$ \\
P2 & $0,2159^{\mathrm{a}} \pm 0,01431$ & $0,8461 \pm 0.0084247$ \\
P3 & $0,2182^{\mathrm{a}} \pm 0,01332$ & $0,8474 \pm 0.0078454$ \\
P4 & $0,2092^{\mathrm{a}} \pm 0,01157$ & $0,8422 \pm 0.0088263$ \\
\hline
\end{tabular}

*) superskrip yang berbeda menunjukkan nilai yang berbeda nyata $(\mathrm{p}<0,05)$

Keterangan:

P1: kontrol

P2: penambahan probiotik A $0,03 \mathrm{~mL} / 15 \mathrm{~L}$

P3: Penambahan Probiotik B 0,03 mL/15L

P4: Penambahan Probiotik C 0,03 mL/15L

Tabel 2. Produksi kadar nitrit selama 30 hari.

\begin{tabular}{ccc}
\hline Perlakuan & Produksi nitrit selama 30 hari \pm SD & Tranformasi $\sqrt{(\mathbf{y}+\mathbf{0 , 5}) \pm \text { SD }}$ \\
\hline P1 & $0,0988^{\mathrm{b}} \pm 0,00404$ & $0,77382 \pm 0,00261$ \\
P2 & $0,0525^{\mathrm{a}} \pm 0,00518$ & $0,74330 \pm 0,00348$ \\
P3 & $0,0513^{\mathrm{a}} \pm 0,00355$ & $0,74249 \pm 0,00239$ \\
P4 & $0,0509^{\mathrm{a}} \pm 0,00644$ & $0,74223 \pm 0,00433$ \\
\hline
\end{tabular}

*) superskrip yang berbeda menunjukkan nilai yang berbeda nyata $(\mathrm{p}<0,05)$

Keterangan:

P1: kontrol

P2: penambahan probiotik A $0,03 \mathrm{~mL} / 15 \mathrm{~L}$

P3: Penambahan Probiotik B $0,03 \mathrm{~mL} / 15 \mathrm{~L}$

P4: Penambahan Probiotik C $0,03 \mathrm{~mL} / 15 \mathrm{~L}$

dan dimasukkan dalam Erlenmeyer $100 \mathrm{ml}$. Sampel ditambah dengan $1 \mathrm{ml}$ larutan sulfanilamide, kemudian akan bereaksi selama 2 menit. Setelah itu ditambahkan 1 ml larutan NED-dihidroklorida kemudian dihomogenkan selama 10 menit hingga berwarna merah keunguan. Larutan dimasukkan diukur menggunakan spektrofotometer dengan panjang gelombang 543 nm.

\section{Pengukuran Suhu, pH, dan DO}

Pengukuran kualitas air penunjang dilakukan setiap pagi, siang, dan sore setiap harinya. Pengukuran suhu menggunakan thermometer, DO menggunakan DO meter, dan $\mathrm{pH}$ menggunakan $\mathrm{pH}$ meter.

\section{Analisis Data}

Pengolahan data dilakukan dengan perhitungan statistik menggunakan metode
ANOVA (Analysis of Variance) untuk mengetahui perlakuan yang diberikan (Kusriningrum, 2012). Data yang diperoleh dari hasil pengukuran setiap hari dicatat, selanjutnya dianalisis dengan menggunakan ANOVA (pada selang kepercayaan 99\%).

\section{Hasil}

\section{Kadar Amonia}

Produksi kadar amonia selama 30 hari pada masing-masing perlakuan dapat dilihat pada Tabel 1. Produksi kadar amonia selama 30 hari dihitung berdasarkan kadar amonia pada hari ke 30 .

Uji statistik terhadap produksi amonia menunjukkan adanya perbedaan yang nyata, dengan $\mathrm{p}<0,05$. Setelah dilakukan Uji Jarak Berganda Duncan (Duncan's Multiple Range Test), diketahui bahwa produksi amonia tertinggi adalah 
pada P1 yaitu tanpa pemberian probiotik. Produksi kadar amonia terendah ditunjukkan oleh $\mathrm{P} 4$ dengan pemberian probiotik $\mathrm{C}$.

\section{Kadar Nitrit}

Nilai produksi kadar nitrit selama 30 hari pada masing-masing perlakuan dapat dilihat pada Tabel 2. Nilai produksi kadar nitrit selama 30 hari dihitung berdasarkan kadar nitrit pada hari ke 30 .

Uji statistik terhadap produksi menunjukkan adanya perbedaan yang nyata, dengan $\mathrm{p}<0,05$. Setelah dilakukan Uji Jarak Berganda Duncan (Duncan's Multiple Range Test), dapat diketahui bahwa perbedaan yang nyata antara pelakuan kontrol dengan perlakuan pemberian probiotik. Tetapi, pada perlakuan dengan penambahan probiotik A (Bacillus subtilis, Bacillus apiarius, Lactobacillus plantarum, dan Nitrosomonas europea $1 \times 10^{6}$ CFU), B (Bacillus subtilis dan Bacillus licheniformes $\left.1 \times 10^{7} \mathrm{CFU}\right)$, dan $\mathrm{C}$ (Bacillus subtilis, dan Bacillus licheniformes) $1 \times 10^{12} \mathrm{CFU}$ ) tidak berbeda nyata. Akumulasi kadar amonia yang diproduksi oleh ikan selama pemeliharaan adalah pada perlakuan kontrol sebesar 0,2641 mg/L, perlakuan probiotik B (Bacillus subtilis dan Bacillus licheniformes)

Tabel 3. Kadar Suhu, pH, dan DO selama 30 hari

\begin{tabular}{cccccc}
\hline \multirow{2}{*}{ No } & \multirow{2}{*}{ Parameter } & Kontrol & Probiotik A & Probiotik B & Probiotik C \\
& & $26,6-30,0$ & $26,7-30,0$ & $26,7-30,0$ & $26,6-30,0$ \\
1 & Suhu $\left({ }^{\circ} \mathrm{C}\right)$ & $6,3-8,9$ & $6,3-8,9$ & $6,3-9,0$ & $6,4-8,4$ \\
2 & DO $(\mathrm{mg} / \mathrm{l})$ & $7,23-8,26$ & $7,35-8,15$ & $7,29-8,20$ & $7,22-8,26$ \\
3 & $\mathrm{pH}$ & & &
\end{tabular}

produksi nitrit tertinggi adalah pada P1 yaitu tanpa pemberian probiotik. Produkai nitrit terendah ditunjukkan oleh $\mathrm{P} 4$ dengan pemberian probiotik C. Perlakuan kontrol (P1) tanpa pemberian bakteri probiotik berbeda nyata dengan P2, P3, dan P4, dimana P2, P3, dan P4 tidak memiliki perbedaan yang nyata.

\section{Suhu, pH, dan DO}

Data kisaran kualitas air setelah pemeliharaan selama 30 hari dengan perlakuan penambahan probiotik yang mengandung bakteri heterotrof, dapat dilihat pada Tabel 3. Pengamatan terhadap suhu, dan DO dilakukan setiap pagi dan sore. Pengamatan terhadap $\mathrm{pH}$ setiap sehari sekali, dan pengamatan terhadap nitrat setiap dua hari sekali selama masa pemeliharaan.

Hasil pengukuran terhadap produksi amonia selama 30 hari menunjukkan adanya sebesar 0,2182 $\mathrm{mg} / \mathrm{L}$, perlakuan probiotik A (Bacillus subtilis, Bacillus apiarius, Lactobacillus plantrarum, dan Nitrosomonas europea) sebesar 0,2159 mg/1, dan probiotik C (Bacillus subtilis, Bacillus licheniformes) sebesar 0,2093 mg/L.

Kadar amonia pada perlakuan kontrol hari ke 30 mencapai 0,2641 mg/L. Pada konsentrasi ini, konsentrasi amonia masih dalam ambang yang cocok untuk kehidupan ikan lele. Menurut Stickney (2005), bahwa kandungan amonia yang masih bisa di tolerir oleh ikan adalah $<0,8$ $\mathrm{mg} / \mathrm{L}$. Sehigga konsentrasi amonia pada perlakuan kontrol masih dapat di tolerir oleh ikan lele. Diduga bahwa tingginya nilai amonia pada perlakuan kontrol adalah karena menumpuknya sisa pakan dan feses dalam perairan. Hal ini sesuai dengan pendapat Spotte (1970), bahwa sisa pemberian pakan menghasilkan bahan organik yang membentuk amonia, nitrit, dan nitrat 
pada perairan. Keberadaan amonia dalam perairan mampu mempengaruhi kehidupan ikan karena mereduksi masukan oksigen akibat rusaknya insang, menambah energi untuk detoksifikasi, mengganggu osmoregulasi, dan mengakibatkan kerusakan fisik pada jaringan (Boyd, 1990).

Pada perlakuan dengan pemberian bakteri probiotik $\mathrm{A}, \mathrm{B}$, dan $\mathrm{C}$ produksi amonia pada hari ke 30 secara berturut-turut berada pada konsentrasi 0,2159 $\mathrm{mg} / \mathrm{L}$; 0,2182 $\mathrm{mg} / \mathrm{L}$; dan 0,2093 $\mathrm{mg} / \mathrm{L}$. Pada konsentrasi tersebut, kadar amonia lebih rendah daripada perlakuan kontrol. Sehingga dapat dikatakan bahwa perlakuan dengan penambahan bakteri probiotik $\mathrm{A}, \mathrm{B}$, dan $\mathrm{C}$ lebih baik daripada perlakuan tanpa probiotik. Kadar amonia selama masa pemeliharaan masih berada pada batas aman untuk kehidupan ikan lele sesuai dengan pendapat Stickney (2005) yaitu $<0,8 \mathrm{mg} / \mathrm{L}$.

Akumulasi amonia pada perlakuan menggunakan probiotik C (Bacillus subtilis, Bacillus licheniformes) menunjukkan jumlah yang terendah pada akhir pemeliharaan. Hal ini diduga karena jumlah kepadatan bakteri penyusun probiotik $\mathrm{C}$ (Bacillus subtilis, Bacillus licheniformes) lebih tinggi yaitu $1 \times 10^{12} \mathrm{CFU}$, sedangkan pada probiotik A (Bacillus subtilis, Bacillus apiarius, Lactobacillus plantrarum, dan Nitrosomonas europea) hanya memiliki kepadatan $1 \times 10^{6}$ CFU dan probiotik $\mathrm{B}$ (Bacillus subtilis dan Bacillus licheniformes) memiliki kepadatan $1 \times 10^{7} \mathrm{CFU}$. Tingginya kepadatan bakteri yang diberikan kedalam media, dapat menjadikan akumulasi bahan organik dalam media semakin berkurang karena pemanfaatan bahan organik oleh bakteri. Sehingga produksi ammonia dan nitrit dan berasal dari akumulasi bahan organik dapat menurun.

Menurut Ruyitno et al, (1993) bahwa bakteri heterotrofik dalam pertumbuhannya memerlukan senyawa organik. Sisa pemberian pakan menghasilkan bahan organik yang membentuk amonia, nitrit, dan nitrat pada perairan (Spotte, 1970). Kandungan bakteri yang tedapat pada masing-masing probiotik memanfaatkan bahan organik dalam media. Bahan organik tersebut dimanfaatkan bakteri sebagai sumber energi untuk pertumbuhan bakteri (Sugita et.al., 1985).

Bakteri heterotrof mengawali tahap degradasi senyawa organik dengan serangkaian tahap reaksi enzimatis. Menurut Suarsini (2006), Bacillus sp. memiliki enzim ekstraseluler yang dapat membatu pencernaan dan mampu memperbaiki kualitas air melalui penguraian dan perombakan bahan organik dalam air.

Selain menguraikan bahan organik, penghasil ammonia, nitrit, dan nitrat, bakteri hetrerotrof juga mampu memperbaiki kualitas air dengan menurunkan kadar amonia dalam perairan. Hal ini sesuai pendapat Avnimelech (1999), bahwa bakteri heterotrof mencegah terjadinya akumulasi nitrogen organik dalam media budidaya yang dapat menurunkan kualitas air.

Pada ketiga probiotik yang digunakan, masing-masing probiotik me-miliki kandungan dua spesies bakteri heterotrof dari golongan Bacillus yaitu Bacillus subtilis dan Bacillus licheniformes pada probiotik B, dan C, serta Bacillus subtilis dan Bacillus apiarius pada probiotik A.

Dugaan lainya adalah jenis bakteri Bacillus subtilis dan Bacillus licheniformes pada probiotik $\mathrm{B}$, dan $\mathrm{C}$, serta Bacillus subtilis dan Bacillus apiarius pada probiotik A berperan dalam penyerapan amonia dalam media pemeliharaan. Hal ini didukung oleh pendapat Todar (2002), bahwa bakteri heterotrof berregenerasi lebih cepat dengan memanfaatkan amonia sebagai sumber energi untuk memperbanyak sel dan Brune et.al., (2003) bahwa penurunan kadar amonia terjadi antara lain karena adanya pemanfaatan ammonia oleh proses heterotrofik biosintsis bakteri yang meng- 
hasilkan biomasa bakteri. Sedangkan menurut Ebeling et.al., (2006) proses pengubahan nitrogen dalam sistem akuakultur salah satunya adalah proses heterotrofik bakterial yang mengubah amonia langsung menjadi biomasa bakteri. Bakteri heterotrof yang tumbuh dan berkembang dalam media dapat dimanfaatkan oleh ikan sebagai sumber pakan (McGraw, 2002).

Hasil pengamatan terhadap produsi kadar nitrit selama 30 hari dapat dilihat di Lampiran 5. Fluktuasi kadar nitrit harian dapat dilihat pada Gambar 5. Pada grafik fluktuasi harian nitrit menunjukkan bahwa konsentrasi nitrit pada perlakuan kontrol lebih tinggi daripada pada perlakuan mengunakan probiotik $\mathrm{A}($ Bacillus subtilis, Bacillus apiarius, Lactobacillus plantarum, dan Nitrosomonas europea $1 \times 10^{6}$ CFU), B (Bacillus subtilis dan Bacillus licheniformes $\left.1 \times 10^{7} \mathrm{CFU}\right)$, dan $\mathrm{C}$ (Bacillus subtilis, Bacillus licheniformes $1 \times 10^{12} \mathrm{CFU}$ ) tidak berbeda nyata. Adanya senyawa nitrit pada perairan menunjukkan adanya proses nitrifikasi dalam media pemeliharaan.

Konsentrasi nitrit tertinggi adalah pada perlakuan kontrol, pada hari ke 30, dengan konsentrasi sebesar 0,0988 mg/L. Kadar nitrit pada perlakuan kontrol sangat berbahaya bagi ikan. Tingginya kadar nitrit dalam perlakuan kontrol diduga karena karena tidak adanya organisme yang mengubah atau memanfaatkan nitrit dalam perairan. Salah satu yang menyebabkan ikan mengalami kematian adalah tingginya kadar nitrit yang tinggi pada media. Hal ini sesuai pendapat Moore (1991), apabila kadar nitrit dalam perairan $>0,05 \mathrm{mg} / \mathrm{L}$ dapat bersifat toksik bagi organisme perairan.

Menurut Effendi (2003), pengaruh senyawa nitrit pada ikan adalah terjadinya perubahan transport oksigen, sehingga terjadi kekurangan oksigen dalam tubuh ikan. Hal ini disebabkan oleh Haemoglobin dalam darah yang seharusnya mengikat oksigen berganti mengikat nitrit sehingga masuk kedalam darah. Menurut Yuningsih (2000), apabila perubahan $\mathrm{Hb}$ menjadi MetHb mencapai 20\%-30\% dari Hb normal maka akan terjadi hypoxia, yaitu kekosongan oksigen dalam darah ikan yang keracunan nitrit sehingga darah tidak sanggup lagi lagi megangkut oksigen. Apabila perubahan $\mathrm{Hb}$ menjadi MetHb mencapai 80\%-90\% maka terjadi kondisi yang dapat menyebabkan keracunan bagi ikan.

Nitrit pada media dihasilkan dari akumulasi bahan organik dalam perairan yang manghasilkan amonia, dan kemudian mengalami nitrifikasi sehingga terentuk senyawa nitrit dalam media. Tingginya senyawa nitrit pada perlakuan kontrol diduga karena akumulasi ammonia yang tinggi dan tidak dimanfaatkan atau tidak diubah oleh bakteri menjadi bentuk nitrat. Sesuai dengan pendapat Van Wyk and Scrapa (1999), bahwa akumulasi nitrit pada perairan terjadi apabila proses lanjutan dari nitrifikasi yang mengubah nitrit menjadi nitrat tidak dapat berjalan.

Dari hasil Uji Duncan terhadap kadar nitrit pada perlakuan dengan probiotik A, B, dan $C$ tidak menunjukkan perbedaan yang nyata. Peningkatan nitrit pada perlakuan A, $\mathrm{B}$, dan $\mathrm{C}$ secara berturut-turut adalah 0,0525 $\mathrm{mg} / \mathrm{L} ; 0,0513 \mathrm{mg} / \mathrm{L}$; dan 0,0509 mg/L. Pada konsentrasi tersebut, kadar nitrit dalam perairan mulai berbahaya bagi ikan, karena kadar nitrit dalam media $>0,05 \mathrm{mg} / \mathrm{L}$.

Akumulasi nitrit pada perlakuan menggunakan probiotik C (Bacillus subtilis, Bacillus licheniformes $1 \times 10^{12} \quad$ CFU) menunjukkan bahwa kadar nitrit pada media adalah yang terendah pada akhir pemeliharaan. Kemungkinan yang terjadi adalah rendahnya jumlah ammonia dalam perlakuan dengan pemberian probiotik $\mathrm{C}$, yang bisa diubah melalui proses nitrifikasi menjadi senyawa nitrit. Selain itu, senyawa nitrit dapat dimanfaatkan oleh bakteri 
heterotrof. Pada masa pertumbuhan bakteri heterotrof mereduksi nitrit menjadi ammonium untuk digunakan dalam sintesis biomasa (Gottschalk, 1986).

Fluktuasi suhu harian menunjukkan bahwa suhu pada pagi hari pada kisaran 26$28^{\circ} \mathrm{C}$, dan $28-30^{\circ} \mathrm{C}$ pada sore hari. Konsentrasi suhu ini masih berada dalam batas normal suhu yang baik untuk ikan, sesuai dengan pendapat Hepher and Pruginin (1981), bahwa kisaran suhu yang baik bagi pertumbuhan ikan adalah antara $25^{\mathrm{O}} \mathrm{C}-$ $30^{\circ} \mathrm{C}$. Menurut Effendi (2003), suhu mempengaruhi laju pertumbuhan ikan, metabolisme, serta nafsu makan ikan.

Menurut Effendi (2003), suhu mempengaruhi kadar DO dalam air. Pada saat suhu rendah kadar DO naik, dan pada saat suhu tinggi kadar DO menurun. Konsentrasi DO selama pemeliharaan berada pada kisaran 6,3 - 9,0 mg/L. Kisaran ini hampir sama pada semua perlakuan, dan masih berada pada batas aman. Hal ini mengacu pada pendapat Fortheath et.al., (1993) bahwa kadar aman DO untuk ikan adalah $>5 \mathrm{mg} / \mathrm{l}$. Apabila kadar DO dalam perairan rendah dapat berakibat terhadap pertumbuhan dan penurunan nafsu makan ikan (Boyd, 1982).

DO memegang peran penting dalam proses budidaya intensif yang menggunakan tehnologi bioremediasi. Hal ini dikarenakan aktifitas mikroorganisme pendekomposisi bahan organik memerlukan cukup oksigen. Pada hasil pengamatan, DO pada sore hari cenderung lebih tinggi daripada pagi hari. Menurut Maryam (2010), tingginya kadar DO pada siang hingga sore hari adalah karena adanya aktifitas fotosintesis oleh fitoplankton pada media pemeliharaan, sedangkan penurunan DO pada malam hingga pagi hari karena tingginya konsentrasi $\mathrm{CO}_{2}$ hasil dari respirasi ikan, fitoplankton, serta organism lain dalam media pemeliharaan.
Nilai $\mathrm{pH}$ dalam perairan menggambarkan tentang kondisi asam basa suatu perairan. Pada tabel 5.3, menunjukkan bahwa nilai $\mathrm{pH}$ dalam perairan pada semua perlakuan berada dalam kisaran normal, antara 7,22 - 8,26. Menurut Boyd (1982), $\mathrm{pH}$ berada dibawah 6,5 atau lebih tinggi dari 9,0 dapat menurunkan kemampuan reproduksi dan pertumbuhan ikan. Dengan demikian konsentrasi $\mathrm{pH}$ pada semua perlakuan masih dalam kondisi yang normal dan tidak berbahaya bagi ikan.

\section{Kesimpulan}

Perlakuan dengan pemberian
probiotik yang mengandung bakteri heterotrof berpengaruh terhadap produksi kadar amonia dan nitrit, dengan produksi terendah oleh probiotik C (Bacillus subtilis, dan Bacillus licheniformis, dengan total count $1 \times 10^{12}$ ) dengan kadar amonia sebesar 0,2029 mg/L dan kadar nitrit sebesar 0,0509 $\mathrm{mg} / \mathrm{L}$. Budidaya ikan lele dumbo pada sistem tanpa pergantian air dengan menggunakan probiotik yang tersusun oleh dominasi bakteri heterotrof jenis Bacilus dapat diaplikasikan untuk menanggulangi tingginya akumulasi ammonia dan nitrit selama budidaya

\section{Daftar Pustaka}

Andriyanto, S., N. Listyanto., dan R. Rahmawati. 2010. Pengaruh Pemberian Probiotik Dengan Dosis yang Berbeda terhadap Sintasan dan Pertumbuhan Benih Patin Jambal (Pangaisus djambal). Prosiding Forum Inovasi Teknologi Akuakultur 2010. 117-122 hal.

Avnimelech, Y. 1999. Carbon Nitrogen Ratio as a Control Element in Aquaculture System. Aquaculture. 176. 227-235 pp.

Boy, C.E. 1982. Water Quality Management for Pond Fish Culture. Elsevier 
Scientific Publishing. Co. Amsterdam. 319 p.

Boyd, C.E. 1990. Water Quality Management in Aquaculture and Fisheries Science. Elsevier Scientific Publishing Company. Amsterdam. 3125p.

Brune, D.E., G. Schwartz, A.G. Eversole, J.A Collier, and T.E Schwedler. 2003. Intensification of pond aquaculture and high rate photo-synthetic system. Journal of Aquaculture Engineering. 28. $45-86 \mathrm{pp}$.

Ebeling, J.M., M.B Timmons., and J.J Bisogni. 2006. Engineering Analysis of Thestoichiometry of Photoautotrophic, Autotrophic, and Heterotrophic Removal of AmmoniaNitrogen in Aquaculture Systems. Aquaculture. 257: 346-358 pp.

Effendi, H. 2003. Telaah Kualitas Air Bagi Pengelolaan Sumber Daya Lingkungan Peraira. Kanisius. Yogyakarta. 257 hal.

Forteath N., L. Wee, and M. Frith. 1993. Water Quality. In: P. Hart and D. O' Sullivan (eds.). Recirculation Systems: Design, Construction and Management. University of Tasmania at Launceston, Australia.

Gottschalk, G. 1998. Bacterial Metabolism. $2^{\text {nd }}$ Edition. Springer Verlag. New York.

Hepher, B., and Y. Pruginin. 1981. Commercial Fish Farming: with Special Reference to Fish Culture in Israel. John Willey and Son. New York. $261 \mathrm{p}$.

KKP. 2011. Data Statistik Hasil Perikanan dan Kelautan Indonesia Periode 20052009. Kementerian Kelautan dan Perikanan. 2011. 11 hal.

Kusriningrum, R. S. 2012. Perancangan Percobaan. Airlangga University Press. Surabaya. 43 hal.
Mahyudin, K. 2008. Panduan Lengkap Agribisnis Lele. Penebar Swadaya. Jakarta.

McGraw, W.J. 2002. Utilization Of Heterotrophic And Autotrophic Bacteria In Aquaculture. Global Aquaculture Advocate. December 2002. 82-83 Pp.

Moore, A. 1991. Engineering Analysis of Thestoichiometry of Photoautotrophic, Autotrophic, and Heterotrophic Removal of AmmoniaNitrogen in Aquaculture Systems. Aquaculture, 257: 346-358 pp.

Purnomo, P. D. 2012. Pengaruh Penambahan Karbohidrat pada Me-dia Budidaya Pemeliharaab terhadap Produksi Budidaya Intensif Nila (Oreochromis niloticus). Journal of Aquaculture Management and Technology. Vol 1. No.1.161-179 hal.

Rosmaniar. 2011. Dinamika Biomassa Bakteri dan Kadar Limbah Nitrogen pada Budidaya Ikan Lele (Clarias gariepinus) Intensif secara Sistem Heterotrofik. Skripsi. Universitas Islam Negeri Syarif Hidayatullah. Jakarta.

Sari, N.W., I. Lukistyowati., dan N. Aryani. 2012. Pengaruh pemberian Temulawak (Curcuma xanthorriza Roxb) terhadap Kelulushidupan Ikan Mas (Cyprinus carpio L.) Setelah Diinfeksi Aeromonas hydrophilla. Jurnal Perikanan dan Kelautan. Vol. 17:2. Tahun 2012. 43-59 hal.

Shafrudin, D., Yuniarti dan M. Setiawati. 2006. Pengaruh Kepadatan Benih Ikan Lele Dumbo (Clarias sp.) terhadap Produksi pada Sistem Budidaya dengan Pengendalian Nitrogen Melalui Penambahan Tepung Terigu. Jurnal Akuakultur Indonesia. Vol. 5(2) : 137-147 hal.

Sitompul, S.O., E. Harpeni., dan B. Putri. 2012. Pangaruh Kepadatan Azolla sp. yang Berbeda terhadap Kualitas Air 
dan Pertubuhan Ikan Lele Dumbo pada Sistema Tanpa Ganti Air. Jurnal Rekayasa Dan Teknologi Budidaya Perairan. Vol.1:1. Oktober.2012.

Spotte, S. H. 1970. Fish and Invertebrate Culture: Water Management in Closed System. Wiley Interscience. New York. 145 p.

Stadar Nasional Indonesia. 2004. Cara Uji Nitrit $\left(\mathrm{NO}_{2}\right)$ secara Spektrofotometri. dalam : Air dan Limbah: 9. SNI 066989.9-2004. Badan Standarisasi Nasional. Jakarta.

Stickney, R. R. 1979. Principles of Warmwater Aquaculture. A Wiley-Interscience Publication, John Wiley \& Sons, Inc. New York.125 p.

Stickney, R.R., 2005. Aquaculture: An introductory text. CABI Publishing. USA.256 p.

Suarsini, E. 2006. Bioremediasi Limbah Cair Rumah Tangga menggunakan Konsorsia Bakteri Indigen yang Berpotensi Pereduksi Polutan. Disertasi. Program Studi Pendidikan Biologi. Universitas Negeri Malang.

Sugita, H., U. Satoshi., K. Daiju., and D. Yoshiaki . 1985. Changes in the Bacterial Composition of Water in a Carp Rearing Tank. In: Aquaculture. Elsvier. Amsterdam. 243-247 pp.

Todar, K. 2002. Growth Of Bacterial Population. Texbook Of Bacteria.

Van Wyk P, and J. Scarpa. 1999. Water Quality Requirements and Management. in: P. Van Wyk, R. Davis-Hodgkins, K.L Laramore, J. Main, Mountain, and J. Scarpa. Farming Marine Shrimp in Recirculating Freshwater Systems. 